\title{
BIOSTRATIGRAPHIC AND PALEOZOOGEOGRAPHIC REVIEW OF THE UPPER APTIAN-ALBIAN OSTRACODS OF RIACHUELO FORMATION, SERGIPE- ALAGOAS BASIN, NORTHEASTERN BRAZIL
}

\author{
LUCAS SILVEIRA ANTONIETTO, DERMEVAL APARECIDO DO CARMO \\ Laboratório de Micropaleontologia, Instituto de Geociências, Universidade de Brasília, Campus Darcy Ribeiro, 70919-970, \\ Brasilia, DF, Brazil.antoniettols@gmail.com,delei@gmail.com \\ MARTA CLAUDIA VIVIERS \\ PETROBRAS-CENPES/DIVEX, Cidade Universitária, Quadra 7, Ilha do Fundão, 21949-900, Rio de Janeiro, RJ, Brazil. \\ mcviviers@petrobras.com.br \\ RODRIGO RODRIGUES ADÔRNO \\ Serviço Geológico do Brasil, DEGEO/DIPALE-CPRM/REPO, Avenida Lauro Sodré, 2561, CEP. 76801-581, Porto Velho, \\ Rondônia, Brazil.rodrigo.adorno@cprm.gov.br
}

\begin{abstract}
A biostratigraphic and paleozoogeographic revision of the upper Aptian-Albian ostracods of Riachuelo Formation, in the Sergipe-Alagoas Basin, Brazil, was conducted. The studied material comprised 336 samples from several outcrops, along with well cores drilled by Petróleo Brasileiro S.A. (PETROBRAS). After taxonomic analysis, including the description of Reticulocosta edrianae n. sp., a new biozonation scheme was obtained for the Albian interval of that formation, and the paleozoogeographic affinities of the Brazil-Central West Africa province were reviewed through comparison with results published in the current literature. Several changes were made to previously established ostracod zones. A new code for the Aracajuia benderi Zone (OSE-1), MSA-0, was created, with impact in all of its subzones. The names of the Pattersoncypris ex. gr. angulata (OSE-1.1), 'Patellacythere' sp. GA E 27 (OSE1.3 ) and Veenia guianensis (OSE-1.4) subzones were changed to Harbinia sinuata? (MSA-0.1), Praebythoceratina amsittenensis (MSA-0.3) and Reticulocosta edrianae (MSA-0.4), respectively. The Sergipella viviersae Subzone (OSE1.2) had its code changed for MSA-0.2; also, a stratotype was stablished for it, and the lower limit of the subzone was changed, from lower Albian in previous works to upper Aptian. The Metacytheropteon aff. Metacytheropteron sp. GA C 24 Subzone (OSE-1.5) was renamed MSA-0.5. The uppermost Albian Aracajuia antiqua Latest Occurrence Interval Zone (MSA-1) is herein proposed, following the reclassification Aracajuia benderi specimens of the Aracajuia benderi Subzone (OSE-1.6) to Aracajuia antiqua. Paleozoogeographic analyses showed some faunal interchange with Tethyan provinces, beginning in the latest Aptian, at both specific and generic levels. Limited northward marine influxes across the Walvis ridge were also observed during the Albian, while larger scale southward migrations occurred in the early Cenomanian. The presence of Brachycytherinae species in the Brazil-Central West Africa province as early as the Aptian indicates a new zoogeographic origin for this subfamily, while explaining the occurrence of the group in both the Austral realm and part of the Tethyan realm during the Albian.
\end{abstract}

Key words: Early Cretaceous, South Proto-Atlantic ocean, marine ostracods, MSA-1 Zone, province interchange.

RESUMO - Uma revisão bioestratigráfica e paleozoogeográfica dos ostracodes do Aptiano superior-Albiano da Formação Riachuelo, bacia de Sergipe-Alagoas, Brasil, foi proposta no presente trabalho. O material estudado compreendeu 336 amostras de vários afloramentos, juntamente com testemunhos de poços perfurados pela Petróleo Brasileiro S.A. (PETROBRAS). Após a análise taxonômica, incluindo a descrição de Reticulocosta edrianae sp. nov., um novo zoneamento bioestratigráfico foi obtido para a formação, e as afinidades paleozoogeográficas da província Brasil-África Central Ocidental (incluindo a bacia de Sergipe-Alagoas) foram revistas por meio da comparação com resultados publicados na literatura existente. Várias mudanças foram feitas nas biozonas previamente estabelecidas com base em ostracodes. $\mathrm{O}$ código da Zona Aracajuia benderi (OSE-1) foi alterado para MSA-0, com impacto extendido às suas subdivisões. As subzonas Pattersoncypris ex. gr. angulata, (OSE-1.1) 'Patellacythere' sp. GA E 27 (OSE-1.3) e Veenia guianensis (OSE1.4) tiveram seus nomes e espécies guia alterados respectivamente para Harbinia sinuata (MSA-0.1), Praebythoceratina amsittenensis (MSA-0.3) e Reticulocosta edrianae (MSA-0.4), respectivamente. A subzona Sergipella viviersae (OSE-1.2) teve seu código alterado para MSA-0.2; além disso, um novo estratótipo foi proposto para a mesma, e o seu limite inferior foi reposicionado do Albiano inferior para o Aptiano superior. A Subzona Metacytheropteron aff. Metacytheropteron sp. GA C 24 (OSE-1.5) foi renomeada como MSA-0.5. A Zona Diferencial Superior Aracajuia antiqua (MSA-1), do Albiano terminal, é aqui proposta, uma vez que espécimes tidos como fósseis guia para a Subzona Aracajuia benderi (OSE-1.6) são 
aqui identificados como pertencendo à espécie Aracajuia antiqua. Análises paleozoogeográficas evidenciaram intercâmbio de faunas da Província Brasil-África Central Ocidental com províncias Tetianas a partir do Neoaptiano, tanto em nível de espécie quanto de gênero. Influxos marinhos limitados para o norte através da Cordilheira de Walvis também foram observados durante o Albiano, enquanto migração de maior intensidade em direção ao sul ocorreu no Eocenomaniano. A presença de espécies de Brachycytherinae na Província Brasil-Central África Ocidental a partir do Aptiano indica uma nova origem zoogeográfica para esta subfamília, ao mesmo tempo em que explica a ocorrência do grupo tanto em regiões austrais quanto tetianas durante o Albiano.

Palavras-chave: Eocretáceo, proto-oceano Atlântico Sul, ostracodes marinhos, Zona MSA-1, intercâmbio faunístico.

\section{INTRODUCTION}

The present work is a biostratigraphic and paleozoogeographic revision of the upper Aptian-Albian ostracods of the Riachuelo Formation, Sergipe-Alagoas Basin, northeastern Brazil. Its main objectives are to upgrade the biostratigraphic framework based on ostracods for the Albian of the basin and to re-evaluate the correlations between the ostracod biozones and those based on planktic and benthic foraminifera and cephalopods. At the same time, we also seek to determine the relationships between the "Brazil-Central West Africa" biological province proposed by Tambareau (1982) with its counterparts worldwide, through comparison with previous works addressing the same issue.
The Sergipe-Alagoas Basin is a marginal basin located

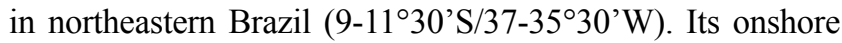
portion is between 16 and $50 \mathrm{~km}$ long and $170 \mathrm{~km}$ wide, covering a total area of approximately $11,000 \mathrm{~km}^{2}$ (Feijó, 1994), bounded by the Pernambuco-Paraíba to the northeast (Maragogi high) and the Jacuípe Basin to the southwest (Itapuã fault) (Figure 1). It has been the subject of several studies, mainly due to the amount of data acquired from efforts such as well and outcrop sampling, investigations of seismic lines and gravimetric and magnetic surveys. Most of these studies have focused on the oil- and gas-producing strata of the basin, i.e., the Carmópolis oil field (Upper Jurassic-Aptian) and the Calumbi Formation (Santonian-Cenozoic) (Marques, 1965; Souza-Lima et al., 2002; Campos Neto et al., 2007; Graddi et al., 2007).

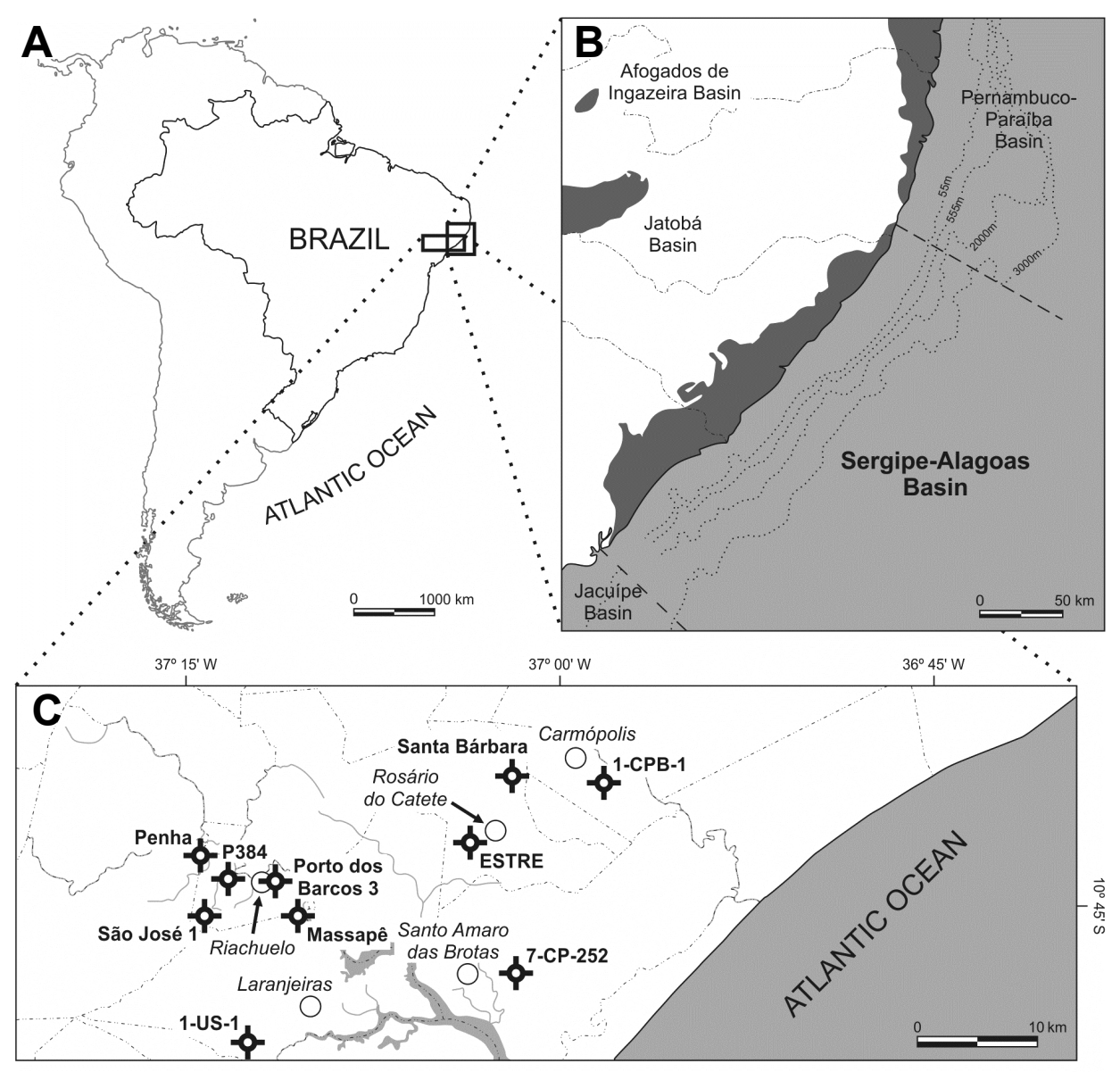

Figure 1. Location of the Sergipe-Alagoas Basin in South America $(\mathbf{A})$ and Brazil $(\mathbf{B})$, along with the outcrops and wells studied in the present work (C). 
Since the first studies on ostracods from the SergipeAlagoas Basin conducted in the 1960s (Krömmelbein, 1962, 1964), the Riachuelo Formation has been at the heart of important discoveries. Viviers et al. (2000) established the first ostracod-based biostratigraphy of the basin (Figure 2), integrating it with previous cephalopod and foraminifer data (Koutsoukos \& Bengtson, 1993) and, in this process, identifying several species in the aforementioned formation. Do Carmo et al. (2008, 2012, 2013), Poropat \& Colin (2012) and Antonietto et al. (2013) presented subsequent taxonomic updates of some of these species.

\section{STUDY AREA}

The Sergipe-Alagoas Basin was originally described by Schaller (1969) as a single basin. However, a later stratigraphic revision by Feijó (1994) considered it as two separate basins, Sergipe and Alagoas, separated by the Japoatã-Penedo high. Campos Neto et al. (2007) recently dismissed the Japoatã-Penedo high as a divisor between them, as it is not observable throughout the entire basin. It is noteworthy that the sedimentary deposits and tectonic style in the basin vary between the states of Sergipe and

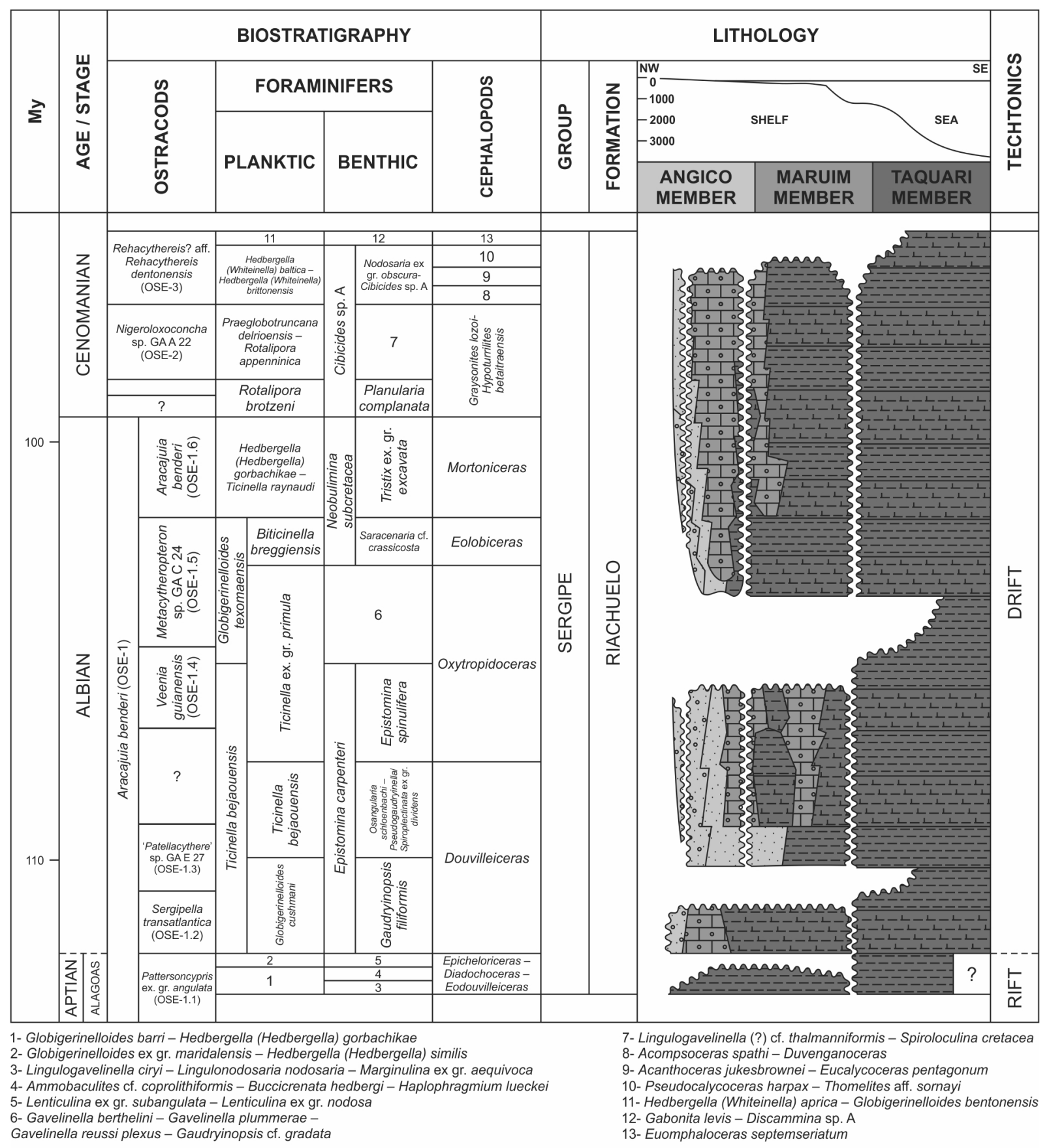

Figure 2. Biostratigraphy of the Albian and early Cenomanian sections of the Sergipe-Alagoas Basin, Brazil, based in ostracodes, foraminifers and cephalopods (modified from Koutsoukos \& Bengtson, 1993; Viviers et al., 2000). 
Alagoas, a reason why they are still considered to be separate sub-basins.

The Sergipe-Alagoas Basin consists of 23 formations, which are correlatable to the evolutionary stages of the formation and expansion of the South Atlantic ocean: syneclise, pre-rift, rift, gulf and drift (Ponte \& Asmus, 1976; Feijó, 1994). In the beginning of the drift phase, initially restricted marine deposits evolved into open sea environments. The early Albian-late Cenomanian Riachuelo Formation was established during this phase, due to a transgression that allowed the sedimentation of openly marine sediments. There are three members of this formation: at the basin margins and grabens, deltaic fans were formed, and the coarse sediments they carried constitute the Angico Member. In lower sedimentation areas, the Maruim Member dominates, with carbonate ramps and dolomitized oolite/oncolite banks deposited under fluctuating sea level conditions. The Taquari Member, on the other hand, corresponds to calcareous mudstone and shale from lagoonal and slope environments. Two third-order sequences are observed in the formation, which are characterized by a highly organic clay basal interval and retrogradational stacking and are interpreted as transgressive systems. A third sequence, with predominantly calcareous deposits and a progradational pattern, is interpreted as a highstand system (Campos Neto et al., 2007).

\section{Regional settings}

The material studied in the present work comprised 147 samples collected from outcrops plus 189 samples from cores drilled by Petróleo Brasileiro S.A. (PETROBRAS) at the Riachuelo Formation, in the State of Sergipe, Brazil (Figures 1, 3), totaling 336 samples (Table 1). The UTM quadrant reference for outcrop coordinates is 24 L (SAD69 default system). The majority of the outcrops (ESTRE, Fazenda Santa Bárbara, Porto dos Barcos 3, Penha, São José 1 and P384) is composed of alternate strata of the Taquari and Angico members. The Maruim Member is only present in the upper part of the Massapê outcrop. No lithology or GPS coordinates were provided by PETROBRAS for wells 1-CPB-1, 7-CP-252 and 1-US-1; however, these wells were previously illustrated in maps by Viviers et al. (2000).

Point ESTRE (713561 N, 8816808 E) in the Municipality of Rosário do Catete begins with marly mudstones that are rich in phytofossils, followed by interbedded carbonate/clay levels. Bioturbed creamy shales with abundant impregnations and fossil-rich siliceous concretions on the top make up the next strata. Immediately above it lie creamy-to-gray carbonate mudstones that are abundant in phytofossils, especially from angiosperms. In the same municipality lies the Fazenda Santa Bárbara outcrop $(716635 \mathrm{~N}, 8821887 \mathrm{E})$, which is considered to be the type section of the Taquari Member of the Riachuelo Formation (Schaller, 1969). The analyzed section comprises reddish calciferous mudstones, with a fossil record consisting of gastropod shells (Family Turritellidae Loven, 1847) as well as possible brachiopods.

The Porto dos Barcos 3 location is situated in the municipality of Riachuelo (699059 N, 8814030 E). From the base to the top, this slightly saprolitic sequence shows levels of creamy calcareous siltstone, followed by alternating creamy and gray calciferous siltstones. Upward, there is a layer of gray-to-yellowish mudstones that become very fossiliferous near the top. Over this mudstone, creamy calciferous siltstones are observed, and the outcrop ends with creamy micaceous mudstones. The fossil record of the outcrop includes echinoderm spines, gastropods and bivalves. Point Penha (692726 N, 8812604 W), also located in Riachuelo, presents a sequence of yellow, calcareous fine sandstones with levels of brachiopod-coquina and sparse phytofossils at its base. This sequence is followed by gray calciferous shales, laminated calcareous siltstones and laminated fine sandstones. Abundant occurrences of bivalves and echinoids are also recorded in these strata.

In the same municipality, the São José 1 outcrop (693824 $\mathrm{N}, 8811279 \mathrm{~W}$ ) presents the most complex lithology among the sampled sites. Basal siltstones with calcareous impregnations are superposed with yellow silty fine sandstones and calciferous yellow siltstones with limestone levels. After a non-observable interval, massive yellow sandstones are recorded, followed

Table 1. Sampled depths analyzed by well in the present work.

\begin{tabular}{|c|c|}
\hline Well & Sampled depth (m) \\
\hline 1-CPB-1 & $198,222,345.5,348,348.5,35,354.5,355.5,356.5,358.5,359.5,360.5,364.5$ \\
\hline 1-US-1 & $\begin{array}{l}0,12,30,60,90,98.5,99.5,100.5,101.1,120,150,180,210,240,246,261,270,270.05,276,291,300,306,321,330,336,351, \\
360,366,381,390,396,399,399.5,400.5,411,420,426,441,450,456,471,480,486,501,510,516,531,540,541,546,552, \\
552.5,553.5,554.5,555.5,561,570,576,591,600,606,621,630,636,651,660,666,678,679.55,681,690,696,711,720,726 \\
741,750,756,771,780,786,801,804,810,816,831,840,846,861,870,876,891,900,906,921,930,936,951,953,953.1,960 \\
966,981,990,996,1011,1020,1026,1041,1050,1056,1067,1067.25,1071,1080,1086,1101,1110,1116,1131,1139.2,1139\end{array}$ \\
\hline $7-\mathrm{CP}-252$ & $\begin{array}{l}466,466.2,466.7,467.5,467.55,467.9,468.7,469.2,469.75,469.8,470.15,470.6,470.65,471.25,471.8,472.25,472.3,472.6, \\
473.3,473.8,474.45,474.5,474.85,475.3,475.85,476.25,476.3,476.5,476.7,477.1,477.5,477.95,478.45,478.85,479.5,480.3, \\
480.55,480.95,481.6,481.8,482.9,483.5,483.55,484.15,484.4,484.75,485.6,486.05,486.45,487,488.15,488.4,489.15,489.2, \\
489.7,490,490.1,490.35,492.95,493,493.45,493.5,494.3,494.75,495.85,495.9,496.55,496.6,497.7,498.3,498.6,502.4, \\
503.35,503.53,506.3,507.15,508.4,508.75,509.3,511.35,511.4,511.9,512.7,514,514.05,515,516,517.45,518.3,518.8,521, \\
521.4,523.9,527.1,534.8,535.55,540.05,552,553.4,558.9,560.3,564.8,567.15,568.15,568.95,581.35\end{array}$ \\
\hline
\end{tabular}


by limestones with abundant bivalves, cephalopods and bioturbations. Towards the top, marl levels with varying amounts of limestone occur, and above them, there are very fossiliferous solid limestones, immediately under a nonrhythmic intercalation of creamy laminated siltstone marls and mudstones, rich in turritelid gastropods. The section ends with the deposition of creamy-to-yellowish, medium-to-thinly laminated calcareous sandstones, with many phytofossils.

Locality P384 (695625 N, 8814175 E), also in Riachuelo Formation, comprises, from the base to the top, creamy calciferous laminated mudstones with bioturbation levels, rich in brachiopods, bivalves and phytoclasts; interbedded yellowish calciferous siltstones and creamy sandstones; and creamy calciferous laminated mudstones. The whole section is abundant in turritelid shells. Point Massapê (700764 N, $881233 \mathrm{~L}$ ), located at the homonymous village in Riachuelo, is the only section addressed in the present work identified as part of the Maruim Member. The lithology of this extensive outcrop begins with yellow-creamy laminated calciferous and micaceous siltstones. Over these siltstones, fine-to-very fine yellowish calciferous/micaceous sandstones occur. These are followed by (in this order) intercalations of yellowto-creamy siltstones and mudstones, gray greywacke with dark impregnations, and, finally, interposed levels of oolitic calcarenites and yellow sandstones with smoky quartz grains, sparse ooids and bioturbations.

\section{MATERIAL AND METHODS}

Samples collected from outcrops during fieldwork were listed, prepared and packaged according to the methodology developed by the Laboratory of Micropaleontology of the University of Brasilia (LabMicro-UnB), Brazil. Sixty grams of each sample were prepared, and the remainder was packed in double plastic bags with catalogue-record sheets. The sample contents separated for preparation were processed as follows: first, they were treated with a solution containing $30 \%$ hydrogen peroxide $\left(\mathrm{H}_{2} \mathrm{O}_{2}\right)$, with the aim of fragmenting rock particles. Ethanol at $92 \mathrm{GL}$ was added to interrupt this reaction, after which separation of grains by size was performed, using mesh sieves of 630, 250, 160 and $80 \mu \mathrm{m}$. For samples MP-1430 to MP-1434, MP-1493, MP1494 and MP-1678, the $80 \mu \mathrm{m}$ sieve was replaced by a 90 $\mu \mathrm{m}-56 \mu \mathrm{m}$ dual set.

Carapaces and valves of several species were studied at LabMicro-UnB and the Smithsonian National Museum of Natural History (NMNH), Washington D.C., United States. The analysis of the additional 189 previously processed samples from PETROBRAS was conducted at the "Centro de Pesquisas Leopoldo Américo Miguez de Mello" (CENPES), Rio de Janeiro, Brazil. After taxonomic analysis of the ostracods present in the samples, a new biozonation scheme for the Albian of the Sergipe-Alagoas

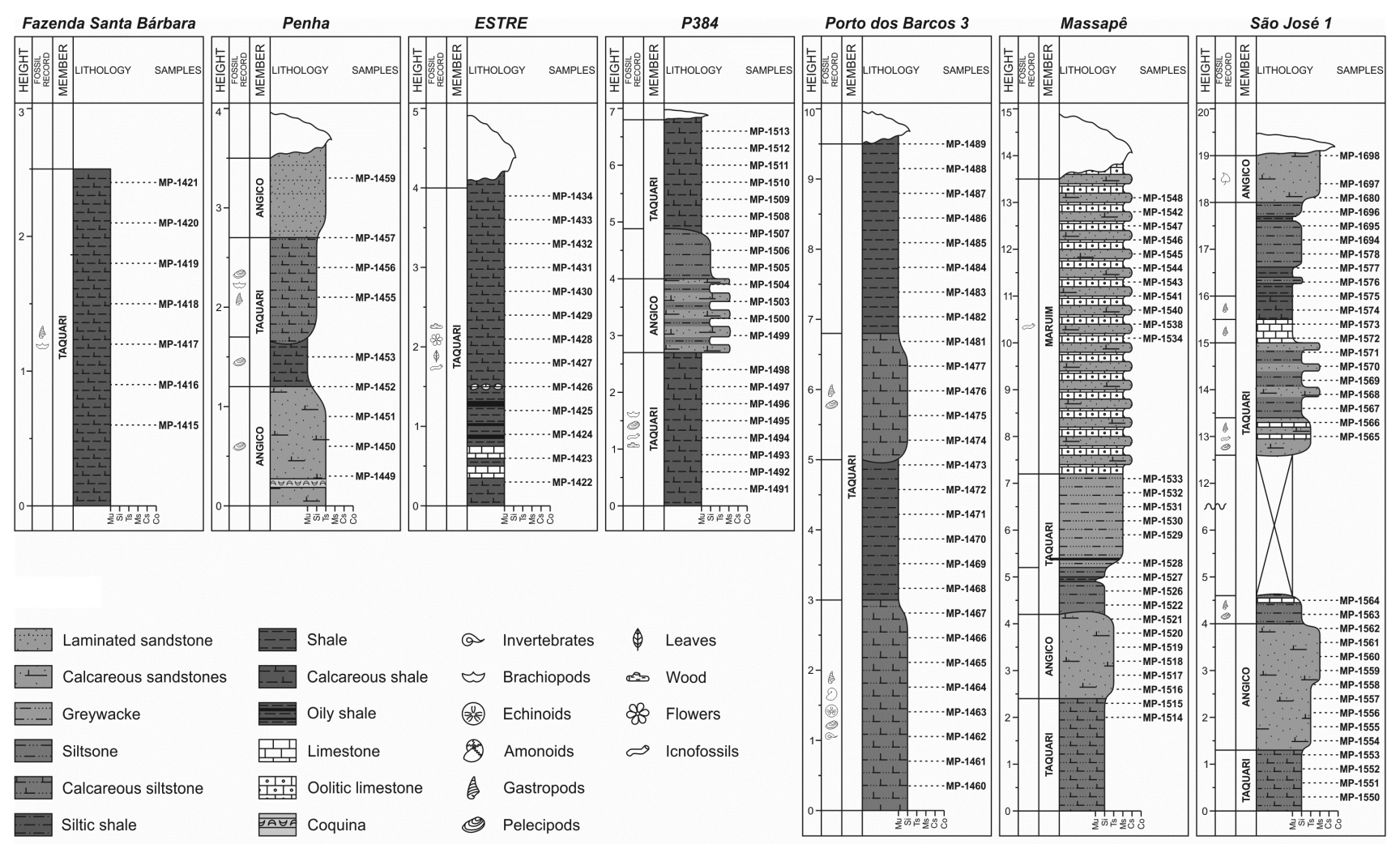

Figure 3. Lithology of sampled Riachuelo Formation outcrops in the Sergipe-Alagoas Basin, Brazil. Samples are numbered from MP-1421 to MP-1698. Abbreviations: MP, Micropaleontological collection of the "Museu de Geociências" of the "Universidade de Brasilia". 
Basin was obtained. The ostracods were also used to revise the paleozoogeographic affinities of the Sergipe-Alagoas Basin with other basins during the Albian-early Cenomanian through comparison with previous results from the current literature on this topic.

\section{RESULTS AND DISCUSSION}

The revision of the ostracod biostratigraphy of the Riachuelo Formation's Albian strata demonstrates the necessity of changes in range and nomenclature of the zones and subzones previously established by Viviers et al. (2000). New information was added to the ostracod zones, in order to improve application and resolution of the analyzed units. In accordance to the "Código Brasileiro de Nomenclatura Estratigráfica" (Murphy \& Salvador, 1999), a new code name for these units, "MSA" ("Marinho de Sergipe-Alagoas"), was established in substitution for the original "OSE". A new interval zone was also formalized in the uppermost Albian of the Riachuelo Formation.

Some specimens identified as Veenia guianensis by Viviers et al. (2000) were guide fossils to one of the subzones of the Albian of the Riachuelo Formation. However, they belong in fact to an entirely new species, Reticulocosta edrianae n. sp., which is herein described. A paleozoogeographic revision is also performed in this work, expanding on the correlations with paleozoogeographic provinces in the northern and southern regions along the Proto-Atlantic ocean.

\section{Systematic paleontology}

The suprafamiliar classification used here follows Liebau (2005), while the taxonomy of lower ranks was based on Gründel (1974). The morphological terminology is the same from Sylvester-Bradley \& Benson (1971), except for the usage of the term "ridge", in which Kesling (1951) is followed. Terms used to describe the curvature of anterior and posterior ends - infra-curvate, equi-curvate and supra-curvate - were adopted from Lüttig (1962). Type materials were housed at the research collection of the Museum of Geosciences, University of Brasilia (UnB), under the prefix CP ("Coleção de Pesquisa").

Subclass OSTRACODA Latreille, 1802 Superorder PODOCOPOMORPHA Kozur, 1972 Order PODOCOPIDA Sars, 1866 Suborder CYTHEROCOPINA Gründel, 1967

Infraorder NOMOCYTHERININA Liebau, 1991 Superfamily TRACHYLEBERIDOIDEA SylvesterBradley, 1948

Family CYTHERETTIDAE Triebel, 1952 Subfamily PALAEOCYTHERIDEINAE Ljubimova, 1955 Tribe CYTHERETTINI Triebel, 1952

\section{Reticulocosta Gründel, 1974}

Type species. Veenia (Veenia) ornatoreticulata Reyment, 1963, by subsequent designation of Gründel (1974).
Reticulocosta edrianae n. sp. (Figures 4A-L)

2000 Veenia guianensis Swain. Viviers, Koutsoukos, SilvaTelles Jr. \& Bengtson, p. 413, fig. 22.10.

2000 Veenia sp. P1. Viviers, Koutsoukos, Silva-Telles Jr. \& Bengtson, p. 410, figs. 23.3, 23.4.

Etymology. Latinized form of "Edriana", first name of Edriana Araújo de Lima. The name of this species is a tribute to her.

Holotype. Female carapace (CP-716).

Alotype. Male carapace (CP-717).

Paratypes. Female carapace (CP-718), female carapace (CP-719), female left valve (CP-720) and male right valve (CP-768).

Type locality and stage. Riachuelo Formation, SergipeAlagoas Basin, Riachuelo Municipality, Sergipe State, Brazil, approximate coordinates: 699059N, 8814030L (UTM 24L quadrant, SAD69 geodesic reference system), Porto dos Barcos 3 outcrop, Sample MP-1461. middle Albian, Aracajuia benderi Zone (MSA-0), Praebythoceratina amsittenensis Subzone (MSA-0.3).

Diagnosis. A species of Reticulocosta distinguished by the following features: carapace ornamentation consisting of three highly acuminate ridges, quite varied in thickness, at dorsal, central and ventral position. Secondary ornamentation includes rounded to foveolate reticulation in several degrees of extension, but always present at the centro-anterior region.

Description. In lateral view, subtriangular to sub-rectangular carapace, with greatest height at the antero-central and greatest length at the central regions. Left valve is larger than the right, overlapping it through the entire free margin, but more intensely at the antero-dorsal, antero-ventral and postero-dorsal margins. Round anterior end, becoming slightly rectilinear close to the dorsal margin, where an obtuse cardinal angle is formed. Round, supra-curvate posterior end, becoming slightly rectilinear close to the dorsal margin, where they form an obtuse cardinal angle; a small caudal process is present. Rectilinear to slightly concave dorsal margin. Rounded ventral margin, with a mild concavity at the oral region. Ornamentation consisting of three highly acuminate ridges, quite varied in thickness, at dorsal, central and ventral position: the generally smooth, curved dorsal one runs from the postero-dorsal to the antero-dorsal region, projecting behind the dorsal margin; the lightly posteriorly nodulate and undulate central one runs from the posterocentral to the central region, where it connects to the reticulate centro-anterior tubercle; and the lightly posteriorly nodulate and curved ventral one runs from the postero-ventral to the antero-ventral region. Two riblets also occur, one originating from the eye tubercle and running along the anterior end, right below it, while the other, irregularly shaped, runs along the ventro-central area, partially covering the ventral margin. Additionally, a series of teeth radiates from the anterior and posterior ends. Secondary ornamentation includes rounded to foveolate reticulation in several degrees of extension, but 


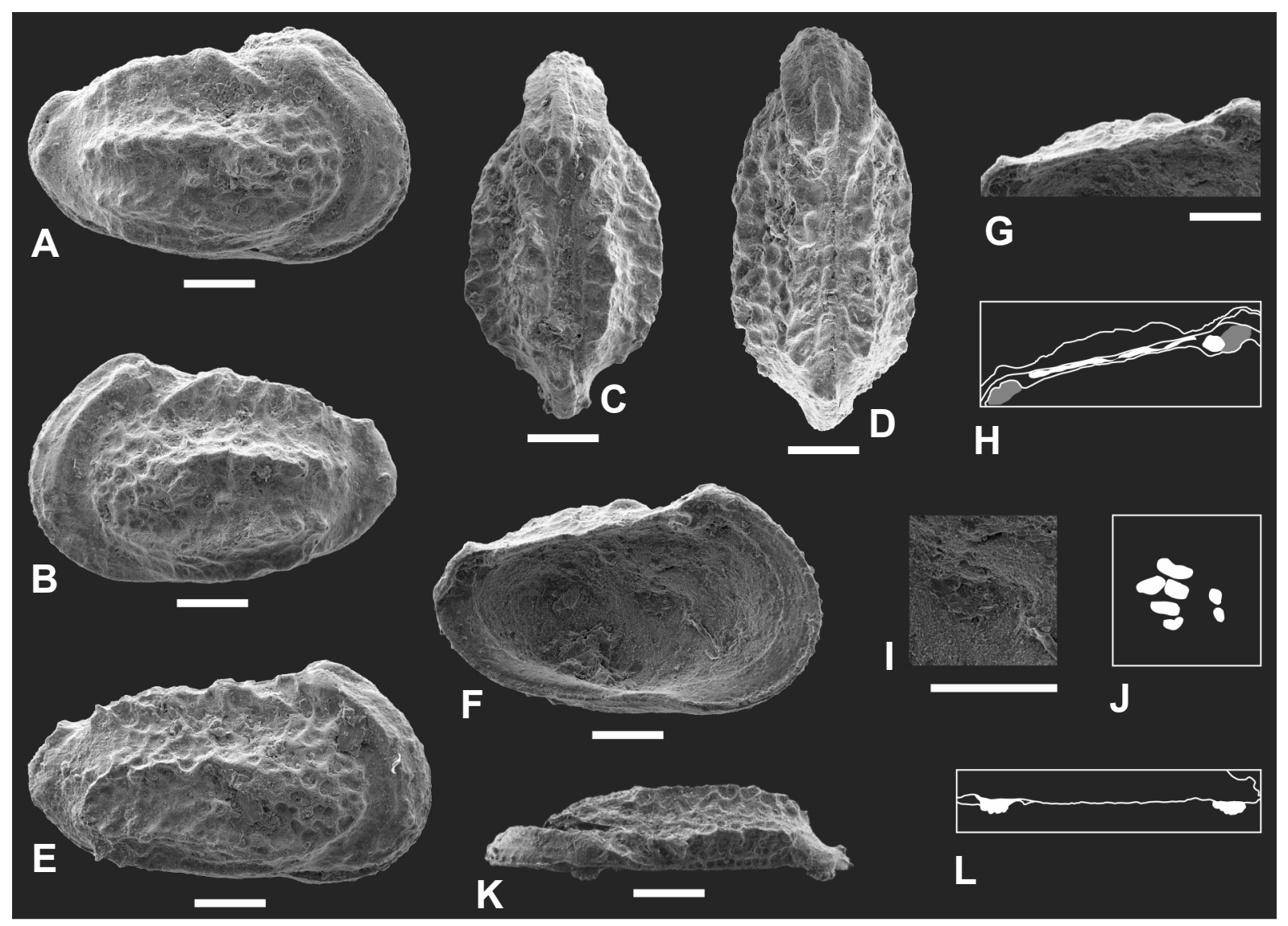

Figure 4. Reticulocosta edrianae n. sp., Riachuelo Formation, Sergipe-Alagoas Basin, Middle Albian, Brazil. A, CP-716, holotype, female carapace, right lateral view. B, CP-718, paratype, female carapace, left lateral view. C, CP-719, paratype, female carapace, dorsal view. D, E, CP-717, alotype, male carapace; D, dorsal view; E, right lateral view. F-J, CP-720, paratype, female left valve; F, internal view; G, detail of the hinge line; $\mathbf{H}$, interpretation of the hinge line structures; I, detail of the central and anterior muscle scars; $\mathbf{J}$, interpretation of the central and anterior muscle scars. K, L, CP-768, paratype, male right valve; K, dorsal view; L, interpretation of the hinge line structures. Scale bars $=100 \mu \mathrm{m}$.

always present at the centro-anterior region; Well-developed rounded eye tubercle. In dorsal view, elliptical, with greatest width at the centro-posterior region; a flat surface is formed between the anterior and posterior cardinal angles and the dorsal ridges. In internal view, Paramphidont hinge, composed of an elliptical, four-lobed tooth in the right valve, followed by an anterior round socket, a smooth bar and a posterior, also four-lobed tooth; elements in the left valve are complementary. Well-developed inner lamela, not visible in the oral region, where the valve margin bends inwards expressively. Selvage is not visible at the postero-ventral and postero-central regions. Central muscle scars group consists of a slightly concave set of four adductor scars, the second from dorsum to venter subdivided in two, and two elliptical frontal scars. Strong sexual dimorphism: females are shorter and more oblong in dorsal view than males, while also presenting thicker ridges and less reticulate ornamentation in general. Interspecific variation observed as follows: degree of reticulation in the carapace lateral surface varying from widespread to concentrate along its central region, and height/ length ratios of the specimens resulting in sturdier or more elongate forms.

Dimensions. CP-716 (holotype), length $0.54 \mathrm{~mm}$, height $0.33 \mathrm{~mm}$, width $0.27 \mathrm{~mm}$; CP-717 (alotype), length $0.57 \mathrm{~mm}$, height $0.31 \mathrm{~mm}$, width $0.26 \mathrm{~mm}$; CP-718 (paratype), length $0.52 \mathrm{~mm}, 0.32 \mathrm{~mm}$, width $0.29 \mathrm{~mm}$; CP-719 (paratype), length $0.52 \mathrm{~mm}$, height $0.31 \mathrm{~mm}$, width $0.28 \mathrm{~mm}$; CP-720 (paratype), length $0.55 \mathrm{~mm}$, height $0.33 \mathrm{~mm}$; CP-768 (paratype), length $0.56 \mathrm{~mm}$, height $0.28 \mathrm{~mm}$.

Occurrence. ESTRE outcrop, samples MP-1423 and MP1424; Fazenda Santa Bárbara outcrop, samples MP-1419 and MP-1420; P384 outcrop, samples MP-1496, MP-1497, MP-1499, MP-1506 and MP-1509 to MP-1513; Porto dos Barcos 3 outcrop, samples MP-1460 to MP-1466, MP1468 to MP-1472, MP-1474 to MP-1477, MP-1481 and MP-1482.

Remarks. Reticulocosta edrianae n. sp. is similar to Reticulocosta tarfayensis (Reyment, 1978), even presenting some degree of intraspecific variation on the reticulate ornamentation, like the latter (see Reyment, 1978; AndreuBoussut, 1991; Majoran, 1991). Even so, the aforementioned species, plus Reticulocosta vitiliginosa (Apostolescu, 1961), differ from the present species by its overall lesser presence of reticulation and sharper ridges, when compared to them (see Apostolescu, 1961). In addition, Reticulocosta edrianae n. sp. has its occurrence restricted to the Lower Cretaceous (Albian), while the others are Upper Cretaceous species (upper Cenomanian-Santonian). 


\section{Biostratigraphy}

According to Viviers et al. (2000), the Albian Stage in the Sergipe-Alagoas Basin originally comprised one zone, Amphycytherura benderi, or OSE-1, later renamed Aracajuia benderi by Antonietto et al. (2013). This zone was subdivided into six subzones from bottom to top: Pattersoncypris ex. gr. angulata, (OSE-1.1); Sergipella transatlantica, (OSE1.2), renamed as Sergipella viviersae Do Carmo et al., 2012 by Do Carmo et al. (2012); 'Patellacythere' sp. GA E 27, (OSE-1.3); Veenia guianensis Swain, 1976, (OSE-1.4); Metacytheropteron aff. $M$. sp. GA C 24, (OSE-1.5); and Amphycytherura benderi,(OSE-1.6) - also Aracajuia benderi, after Antonietto et al. (2013). Between subzones OSE-1.3 and OSE-1.4, there was an interval where no zonation based on ostracods could be established, although a transition is observable in the planktic (ending of Ticinella bejaouensis Zone, Ticinella bejaouensis Subzone) and benthic (ending of Epistomina carpenteri Zone, Osangularia schloenbachiPseudogaudryinella/Spiroplectinata ex gr. dividens Subzone) foraminiferal faunas as well as between cephalopods (ending of Douvilleiceras Zone) (Figure 2).

At the present revision of the upper Aptian-Albian stratigraphy of the basin, several changes were made in previously established ostracod zones and subzones, based on the correlation of outcrops and wells analyzed (Figure 5). The OSE-1 Zone and its subzones, OSE-1.1, OSE-1.2, OSE-1.3 and OSE-1.4, are renamed and redescribed below, while OSE-1.5 had only its name changed (MSA-0.5). An entirely new zone, MSA-1, is created in the uppermost Albian of the Riachuelo Formation, susbstituting the former OSE-1.6 Subzone.

\section{Aracajuia benderi Range Zone (MSA-0)}

Definition. Stratigraphic interval corresponding to the local range of Aracajuia benderi Krömmelbein, 1967.

Characterization. From the base to the top, the following subzones are recognized: Harbinia sinuata? (Krömmelbein \& Weber, 1971) (MSA-0.1), Sergipella viviersae (MSA0.2 ), Praebythoceratina amsittenensis Andreu-Boussut, 1991 (MSA-0.3), Reticulocosta edrianae (MSA-0.4) and Metacytheropteron aff. M. sp. GA C 24 (MSA-0.5).

Stage. Upper Aptian-upper Albian.

Stratotype. 1-US-1 well, between depths of 690 and $1161 \mathrm{~m}$, Municipality of Laranjeiras, Sergipe State, Brazil.

Observations. A detailed discussion on the Zone MSA-0 (formerly OSE-1) can be found in Viviers et al. (2000). A stratotype, established in core sections of the 1-US-1 well, is also proposed for MSA- 0 for the first time. Although the zone is not entirely represented in this well (it lacks MSA-0.1, MSA- 0.3 and MSA- 0.4 subzones), this is is the most complete section of MSA-0 so far analyzed.

\section{Harbinia sinuata? Range Subzone (MSA-0.1)}

Definition. Stratigraphic interval corresponding to the local range of Harbinia sinuata?.

Characterization. Interval containing a characteristic association of Harbinia sinuata?, Aracajuia benderi, Sergipella viviersae and Dicrorygma? sp. 1.
Stratotype. 7-CP-252 well, between depths of 478.45 and 484.4 m, Municipality of Santo Amaro das Brotas, Sergipe State, Brazil.

Stage. Upper Aptian.

Observations. A detailed discussion on the MSA-0.1 Subzone (formerly OSE-1.1) can be found in Viviers et al. (2000). This subzone was established using Pattersoncypris ex. gr. angulata (Krömmelbein \& Weber, 1971) as its fossil guide. However, Harbinia sinuata? (Krömmelbein \& Weber, 1971) is more abundant in the studied samples (including the reviewed well material), which justifies its preference as a marker for the interval. A stratotype is also proposed for the subzone for the first time. Additionally, several species from Viviers et al. (2000), such as Ovocytheridea? aff. Ovocytheridea? sp. GA D 6, Pattersoncypris ex. gr. angulata, Conchoecia? sp. Se1 were not observed in the present study.

\section{Sergipella viviersae Latest Occurrence Interval Subzone (MSA-0.2)}

Definition. Lower and upper boundaries of the subzone defined by the last occurrences of Harbinia sinuata? and Sergipella viviersae, respectively.

Characterization. Other species observed in this zone include Cytherella besrinensis (Bischoff, 1964), Cytherelloidea btaterensis Bischoff, 1964, Bairdoppilata pseudoseptentrionalis Mertens, 1956, Cetacella sp. 1, Paracypris eniotmetos Nicolaidis \& Piovesan, 2013, Harbinia crepata Do Carmo et al., 2013, Liasina sp. 1, Praebythoceratina amsittenensis, Praebythoceratina sp. 1, Praebythoceratina reducta (Gründel, 1964), Patellacythere shimonensis (Rosenfeld \& Raab, 1983), Xestoleberis? sp. 2, Dicrorygma sp. 1, Aracajuia benderi, Eocytheropteron sp. 1, Metacytheropteron aff. M. sp. GAC 24 and Metacytheropteron minuta? (Swain, 1976).

Stratotype. 1-CPB-1 well, between depths of 348 and 354.5 m, Municipality of Carmópolis, Sergipe State, Brazil.

Stage. Uppermost Aptian-lowermost Albian.

Observations. A detailed discussion on the MSA-0.2 Subzone (formerly OSE-1.2) can be found in Viviers et al. (2000). The present work formalizes the taxonomic changes made to this subzone by Do Carmo et al. (2012), while proposing a stratotype for it. Originally, this subzone was restricted to the Taquari Member; however, present data show it also occurs in the Angico Member. The occurrence of Harbinia crepata, a characteristic species of the Aptian of Brazil (Do Carmo et $a l ., 2013)$, at the lowest portion of MSA-0.2, associated with other Aptian species (Cytherella besrineensis, Cytherelloidea btaterensis, Patellacythere shimonensis and Aracajuia benderi) led to repositioning the lower limit of this subzone from the lower Albian to the uppermost Aptian. Conchoecia? sp. Se1 was not observed in the present work.

\section{Praebythoceratina amsittenensis Latest Occurrence Interval Subzone (MSA-0.3)}

Definition. Lower and upper boundaries of the subzone defined by the last occurrences of Sergipella viviersae and Praebythoceratina amsittenensis, respectively. 


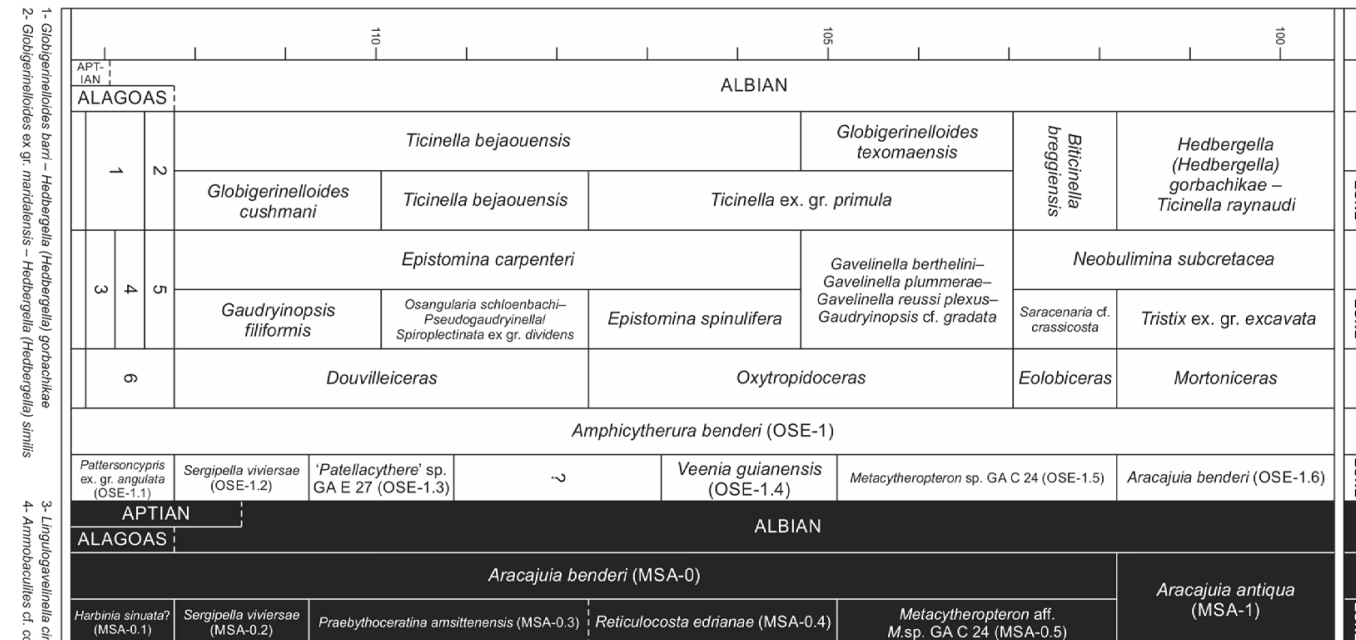

\begin{tabular}{|c|c|c|c|}
\hline & Aracajuia benderi (MSA-0) & & \\
\hline & Reticulocosta edrianae (MSA-0.4) & & \\
\hline & Aracajuia benderi (MSA-0) & & \\
\hline & Reticulocosta edrianae (MSA-0.4) & & \\
\hline & nderi (MSA-0) & & \\
\hline $\begin{array}{l}\text { Sergipella viviersae } \\
\text { (MSA }-0.2)\end{array}$ & & $\begin{array}{l}\text { Metacytheropteron aff. } \\
\text { M. sp. GA C } 24 \text { (MSA-0.5) }\end{array}$ & (MSA-1) \\
\hline & & & $\begin{array}{c}\text { Aracajuia antiqua } \\
\text { (MSA-1) }\end{array}$ \\
\hline
\end{tabular}

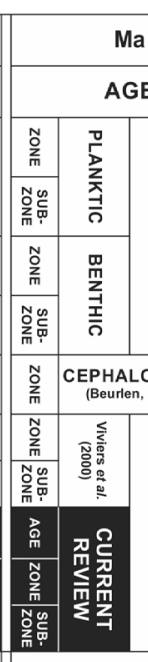
AGE

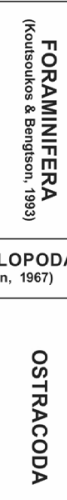

Penha outcrop

São José 1 outcrop

7-CP-252 well

1-CPB-1 well

Porto dos Barcos outcrop

Fazenda Santa Bárbara outcrop

P384 outcrop

ESTRE outcrop

1-US-1 well

Massapê outcrop

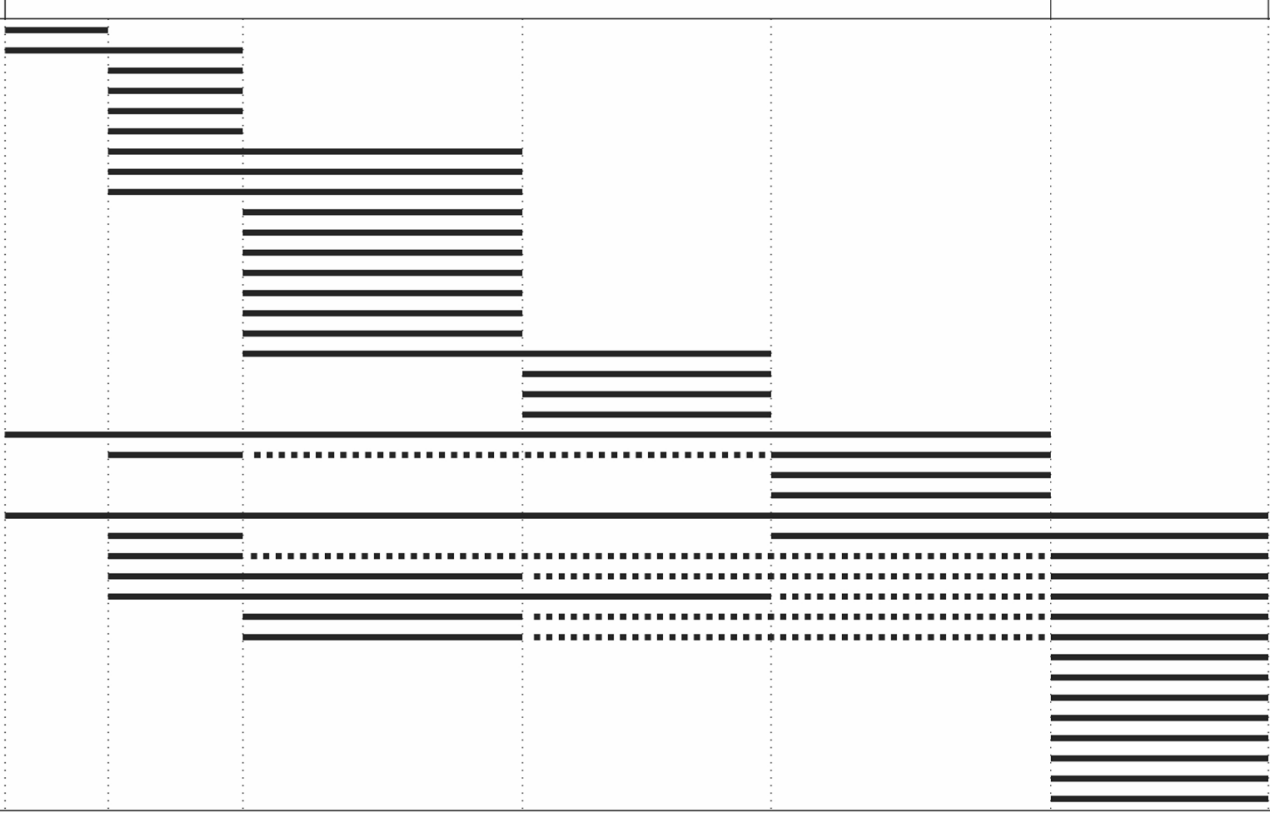


Characterization. The ostracod assemblage of the subzone also comprises Cytherella besrinensis, Cytherelloidea btaterensis, Bairdoppilata pseudoseptentrionalis, Robsoniella falklandensis Dingle, 1984, Paracypris eniotmetos, Praebythoceratina amsittenensis, Patellacythere parva? Weaver, 1982, Xestoleberis? sp. 2, Apatocythere? sp. 1, Dicrorygma? sp. 1, Neocythere tenuis, Aracajuia benderi, Microceratina azazoulensis Andreu \& Colin, 2005, Microceratina? sp. 1, Reticulocosta edrianae n. sp., Algeriana? sp. 1 and Quasihermanites? sp. 1. Among species from Viviers et al. (2000) not observed in the MSA-0.3 Zone in the present revision are Cytherella sp. Se4, Liasina sp. 1, Veenia guianensis (Swain, 1976), Sergipella aff. S. transatlantica Krömmelbein, 1967, Cetacella aff. C. sp. GA D 24 and Metacytheropteron aff. M. sp. GA C 24.

Stratotype. 1-CPB-1 well, between depths of 345.5 and $348 \mathrm{~m}$, Municipality of Carmópolis, Sergipe State, Brazil.

Stage. Lower-middle Albian.

Observations. The species which originally named the MSA0.3 (formerly OSE-1.3) subzone, 'Patellacythere' sp. GA E 27 , was found to actually belong to a group of species in the Family Bythocytheridae Sars, 1926. The figured specimen in Viviers et al. (2000) was reclassified as Patellacythere shimonensis, a species restricted to MSA-0.2 subzone, and most of the material assigned to this species in fact belonged to another taxon, Praebythoceratina amsittenensis. This was particularly true for specimens occurring after the end of MSA-0.2. Therefore, Praebythoceratina amsittenensis is considered to be the real MSA-0.3 marker. A detailed discussion on this subzone can be found in Viviers et al. (2000). The MSA-0.3 subzone was originally restricted to the Angico Member of the Riachuelo Formation; its occurrence is herein expanded to the Taquari Member. Species not observed in the present work include Cytherella sp. Se4, Liasina sp. 1, Veenia guianensis, Sergipella aff. S. transatlantica, Cetacella aff. C. sp. G D 24 and Metacytheropteron aff. M. sp. GAC 24.

\section{Reticulocosta edrianae Latest Occurrence Interval Subzone (MSA-0.4)}

Definition. Lower and upper boundaries of the subzone defined by the last occurrences of Praebythoceratina amsittenensis and Reticulocosta edrianae $\mathrm{n}$. sp., respectively. Characterization. This subzone fauna also includes Cytherella icknieldensis?, Paracypris eniotmetos, Neocythere tenuis, Aracajuia benderi and Aracajuia fragilis (Piovesan \& Nicolaidis, 2013).

Stratotype. Porto dos Barcos 3 outcrop (699059 N, 8814030 E, 24L UTM quadrant reference, SAD69 default system), between 6.7 and $7 \mathrm{~m}$ high from the outcrop base, Municipality of Riachuelo, Sergipe State, Brazil.

Stage. Middle Albian.

Observations. The specimens identified by Viviers et al. (2000) as Veenia guianensis, the fossil guide for MSA-0.4 (formerly OSE-1.4), belong to in reality to Reticulocosta edrianae $\mathrm{n}$. sp.,
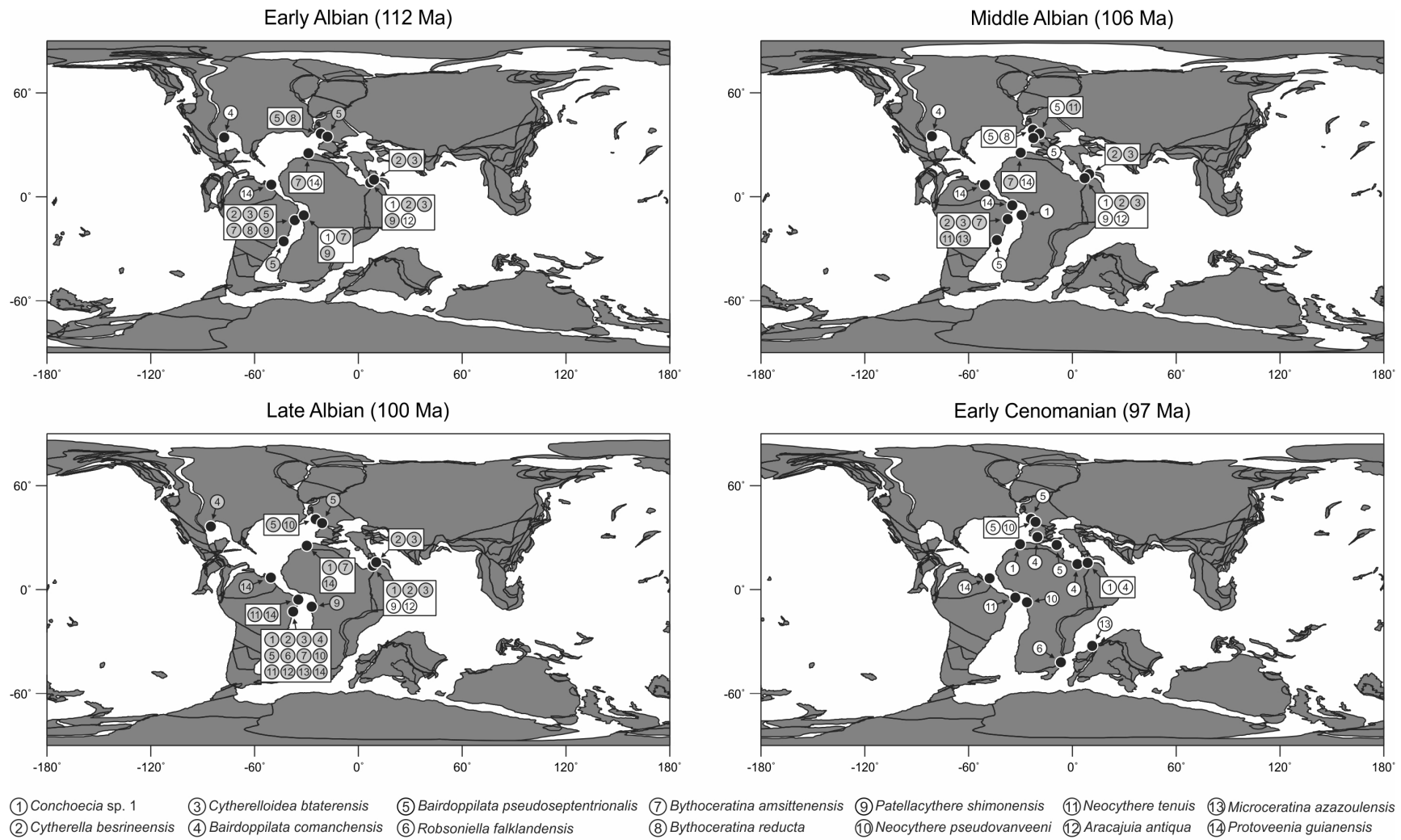

Figure 6. Paleozoogeography of species with occurrences in the Riachuelo Formation, Sergipe-Alagoas Basin, and coeval lithologies worldwide during the Albian and early Cenomanian. Paleomaps were adapted from ODSN (2011). 
leading to the renaming of this subzone. Nevertheless, Veenia guianensis was also found in the present material, though not associated with Reticulocosta edrianae $\mathrm{n}$. sp. Between subzones MSA-0.3 and MSA-0.4, Viviers et al. (2000) observed an absence of any clear biozone marking species, and the interval between these subzones was left open for biozonation. The present work established the contact between MSA- 0.3 and MSA-0.4, although it was not possible to determine when in time it occurred. Therefore, the authors chose to position it along the top limits of Ticinella bejaouaensis Zone (Al2) of planktic foraminifera and Douvilleiceras Zone of ammonites. A detailed discussion on MSA- 0.4 can be found in Viviers et al. (2000). Originally, there was no information about which members of the Riachuelo Formation this subzone was present at; therefore, according to our results, it is restricted to the Angico and Taquari members. Ovocytheridea? sp. Se1 was not observed in the present study.

\section{Aracajuia antiqua Latest Occurrence Interval Zone (MSA-1)} Definition. Lower boundary of the zone defined by the last occurrences of Aracajuia benderi and Metacytheropteron aff. $M$. sp. GA C 24, while the upper boundary is defined by the last occurrence of Aracajuia antiqua.

Characterization. The MSA-1 Zone spans areas nearby the Massapê outcrop and the 1-US-1 well, between the towns of Riachuelo and Laranjeiras, Sergipe State, Brazil. It is observable in Massapê in all members of the Riachuelo Formation. Its thickness varies between 11 (Massapê outcrop) and almost $300 \mathrm{~m}$ (1-US-1 well). Other taxa present in this zone include Cytherella besrinensis, Cytherelloidea btaterensis, Bairdoppilata comanchensis (Alexander, 1929), Bairdoppilata sp. 1, Bairdoppilata sp. 2, Cetacella sp. 1, Paracypris eniotmetos, Xestoleberis? sp. 1, Dicrorygma? sp. 1, Neocythere pseudovanveeni (Gründel, 1966), Eocytheropteron? sp. 1, Microceratina azazoulensis, Veenia guianensis and Brachycythere sp. 1.

Stratotype. 1-US-1 well, between depths of 480 and $681 \mathrm{~m}$, Municipality of Laranjeiras, Sergipe State, Brazil.

Stage. Uppermost Albian.

Observations. Specimens previously considered to be Aracajuia benderi in the OSE-1.6 Subzone, at the top of MSA0 Zone (Viviers et al., 2000), were reclassified as Aracajuia antiqua, creating an entirely new zone in the latest Albian of the Riachuelo Formation, the Aracajuia antiqua Latest Occurrence Interval Zone, after its guiding species, and coded as MSA-1. Although its lower limit is established based in two species, Aracajuia benderi and Metacytheropteron aff. $M$. sp. GA C 24, these two disappear from the fossil record within a slightly different interval between them. Viviers $e t$ al. (2000) did not discuss the distribution of this zone along the Riachuelo Formation; according to present results, it is observable at all members of that formation.

\section{Paleozoogeography}

Original attempts to establish taxon compositionbased relationships between the upper Aptian-Albian ostracodofaunas of the Riachuelo Formation and coeval lithologic units from western Africa indicated great similarity between that unit and the Madiéla Formation in the Gabon Basin, Gabon (Krömmelbein, 1966, 1975; Krömmelbein \& Wenger, 1966; Bertels, 1977; Grosdidier, 1979; Koutsoukos \& Silva-Telles Jr., 1993). Tambareau (1982) even suggested the existence of a "Central Brazil-West Africa" biologic province, based on that similarity. This correlation was later expanded by Koutsoukos \& Dias-Britto (1987) and Piovesan et al. (2013), who observed the co-occurrence of ostracod species and genera of the Riachuelo Formation in other Brazilian shore units, such as the northeasternmost Potiguar and the southeastern Campos and Santos basins.

Dias-Brito (2000), based on the worldwide equatorial occurrence of pithonellids (calcispheres), established the notion of the "Megatethys", or the "Mid Cretaceous Tethyan Realm". According to this concept, the global distribution of pithonellids defined a realm occupying both hemispheres, approximately between latitudes $40^{\circ} \mathrm{N}$ and $40^{\circ} \mathrm{S}$, in the Albian-Turonian time interval. This Megatethys ocean reached its maximum extension in the late Albian, when warm water reached temperate regions and initially tropical organisms made brief incursions into high-latitude areas. The southernmost limit of Megatethys in the Central ProtoAtlantic ocean was coincident with the Walvis ridge, an effective topographic barrier at that time.

The first evidence of faunal similarity between the Riachuelo Formation and strata outside of the central South Atlantic ocean was provided by Colin \& Andreu (1990), while working with halocypridid ostracods. These authors found the formations in eastern Brazil and western Africa to be strongly correlated with those from the North Atlantic ocean, from areas such as the Agadir Basin in Morocco, southern England (Kaye, 1965), the Jura Mountains in Switzerland (Charollais et al., 1977), the Persian Gulf and Israel (Rosenfeld \& Raab, 1983). This observation was partly confirmed by Piovesan et al. (2013), following a review by Andreu (2002), who identified some genera distributed along the Brazilian coast (including the Sergipe-Alagoas Basin) and lithologic units in Morocco.

Reyment (1980) and Dingle (1999) studied the role of the proto-Walvis and Walvis ridges as a geographical barrier between the central and southernmost Atlantic ostracodefaunas during the Berriasian-Santonian. After a taxonomic study of several Cretaceous stages of the Sergipe-Alagoas Basin, Viviers et al. (2000) summarized the relationships of the Riachuelo Formation with strata in several Early-Late Cretaceous realms along the Proto-Atlantic ocean. These correlations were made based in part on the chronologic and geographic distributions of the ostracod genera Conchoecia Dana, 1849, Amphicytherura Butler \& Jones, 1957 and Veenia Butler \& Jones, 1957. A significant faunal renewal was recorded approximately in the middle Cenomanian, with the first appearance in the basin of genera such as Brachycythere Alexander, 1933 and Paracypris Sars, 1866.

Present results corroborate previous assumptions herein summarized about the paleozoogeography of the Riachuelo Formation ostracods, both at specific and generic levels. 
Although the majority of the species identified is endemic to this province, some interchange is observed with Tethyan faunas beginning in the early Albian (Figure 6). Species such as Veenia guianensis and Bairdoppilata comanchensis were shared with North-Central American shores (Veenia guianensis was also found in Africa), while Conchoecia? sp. 1, Cytherella besrinensis, Cytherelloidea btaterensis, Praebythoceratina amsittenensis, Patellacythere shimonensis and Aracajuia antiqua appeared in both Brazil-Central West Africa and the Levantine region in the Middle East (Israel and Lebanon). Bairdoppilata pseudoseptentrionalis, Praebythoceratina reducta, Neocythere pseudovanveeni and Neocythere tenuis co-occurred in the Riachuelo Formation and some of the southern-to-western European basins in England, France and Germany. Two species shared with realms south of the Walvis ridge, Microceratina azazoulensis and Robsoniella falklandensis, probably originated in Brazil-Central West Africa, where they surged in the middle Albian. These species reached the former regions during the Cenomanian.

The exchange of genera between the provinces appeared to follow the same pattern observed at the specific level. Genera such as Cytherella Jones, 1849, Cytherelloidea Alexander, 1929, Bairdoppilata Coryell et al., 1935, Paracypris, Bythoceratina Hornibrook, 1952 and Patellacythere Gründel \& Kozur, 1971 were both geographically and chronologically cosmopolitan. However, some other genera presented a more limited distribution, at least during the Early Cretaceous, and seem to indicate, through their origins, greater paleozoogeographical proximity with the Tethyan realm, such as Dicrorygma Poag, 1962 (see also Christensen, 1965), Neocythere Mertens, 1956, Veenia Butler \& Jones, 1957, Reticulocosta Gründel, 1974, Robsoniella Kuznetsova, 1956 (see also Gramm \& Kuznetsova, 1970) and Microceratina Swanson, 1980 (see also Colin et al., 2005). Sergipella Krömmelbein, 1967 is the only endemic genus of the region, according to the occurrences summarized in Do Carmo et al. (2012).

The genus Aracajuia Krömmelbein, 1967 originated in the Austral province during the Berriasian, prior to becoming very common in this realm during the Hauterivian. However, this genus showed its peak diversity and abundance at the end of the Early Cretaceous (Barremian-Albian), along the shores of Brazil-Central West Africa and the South Mediterranean, extending to the Middle East (Antonietto et al., 2013). According to Dingle (1999), limited northward marine influxes across the Walvis ridge were assumed for the middle Aptian age, while large-scale southward migrations of marine ostracods from the northern sector occurred in early Cenomanian and/or Turonian times. This observation is confirmed by the occurrences of Aracajuia in the early-late Albian of the Sergipe-Alagoas Basin.

Brachycythere appeared to have originated during the Albian, somewhere close to the limits of the North American and African regions of the Tethysian realm (Colin \& Babinot, 1996; Puckett, 2002), although occurrences in India (Austral realm) have also been reported for the same age (Andreu et al., 2008). The presence of Brachycythere sp. 1 in the BrazilCentral West Africa province dates from the late Aptian
(Grosdidier, 1979), much earlier than the previous earliest record for this region, i.e., Brachycythere sapucariensis Krömmelbein, 1964 from the Cenomanian of several Brazilian and African basins (Viviers et al., 2000). Therefore, the geographic origin of the Subfamily Brachycytherinae Puri, 1954 is transferred southwards, which would also explain the occurrence of the group in both the Austral realm and part of the Tethyan realm during the Albian.

\section{CONCLUSIONS}

The present revision of the ostracod biostratigraphy and paleozoogeography of the upper Aptian and Albian stages of the Riachuelo Formation resulted in the description of a new species, Reticulocosta edrianae $\mathrm{n}$. sp. There were also changes in one previously established zone and its six subzones, along with the proposition of an entirely new zone, MSA-1, created in detriment of OSE-1.6 and based on Aracajuia antiqua. The Zone OSE-1, following the present stratigraphic revision, is renamed MSA-0. Its subzones currently being changed include formers OSE-1.1, now MSA- 0.1 and defined by Harbinia sinuata?; OSE-1.2, renamed MSA-0.2 and with a newly designated stratotype; OSE-1.3, henceforth MSA-0.3 and marked by Praebythoceratina amsittenensis; OSE1.4, now MSA-0.4, whose guide species was reclassified as Reticulocosta edrianae n. sp., and its earlier limit was tentatively redefined as the end of OSE-1.3; and OSE-1.5, renamed MSA-0.5.

The present work also allowed a major expansion of the correlations with paleozoogeographic provinces along the Proto-Atlantic ocean. Although the majority of the species from the basin are endemic to the Brazil-Central West Africa province, some interchange is observed with Tethyan faunas, beginning in the early Albian, ranging from North-Central American shores to the Levantine region in the Middle East. Species shared with realms south of the Walvis ridge probably originated in Brazil-Central West Africa in the middle Albian and reached the former regions during the Cenomanian. The exchange of genera between the provinces appears to follow the same pattern observed at the specific level, except for the genus Aracajuia, which emigrated from the southernmost Proto-Atlantic during the Barremian, reaching the central Proto-Atlantic at the end of the Early Cretaceous. Sergipella is the only endemic genus of the region. The presence of Brachycytherine ostracods in Brazil-Central West Africa as early as the late Aptian relocates the geographic origin of this subfamily southwards, while also helping to explain the ocurrences of the group in both the Austral realm and part of the Tethyan realm during the Albian.

\section{ACKNOWLEDGEMENTS}

The authors wish to thank the National Council of Technological and Scientific Development (CNPq), associated with the "Serviço de Compras Internacionais" of UnB, for the acquisition of our scanning electron microscope (SEM) (Project no. 401.794/2010-5). We are also grateful to UnB 
for financial support to the visit to PETROBRAS. Thanks to CENPES for technical support with core sample slides (J.V. Queiroz Neto and J.L. Grillo) and SEM photography (R.S.M. Costa). Special thanks go to the "Agência Nacional do Petróleo, Gás Natural e Biocombustíveis", PETROBRAS and the "Fundação de Empreendimentos Científicos e Tecnológicos" (FINATEC) for financial support through the OSTRAKi project (PETROBRAS/GEO-2007/03676). The first author L.S. Antonietto wishes to thank the Coordination for the Improvement of Higher Education Personnel (CAPES) for granting support that allowed the realization of most of the taxonomic work in the Smithsonian NMNH from July 2013 to July 2014 (Process no. 3604-13-6), and the board of the Institute of Geosciences-UnB, for all the cooperation throughout the process. Last, but not least, the first author thanks the NMNH Paleobiology Department staff members, G. Hunt and C.E. Sanford, for all of their assistance and great joyful moments during his stay at Washington, D.C.

\section{REFERENCES}

Andreu, B. 2002. Cretaceous ostracode biochronology of Morocco. Eclogae Geologicae Helvetiae, 95:133-152. doi:10.5169/ seals-168951

Andreu, B.; Colin, J.P. \& Singh, J. 2008. Cretaceous (Albian to Coniacian) ostracodes from the subsurface of the Jaisalmer Basin, Rajasthan, India. Micropaleontology, 53:345-370. doi: 10.2113/gsmicropal.53.5.345

Andreu-Boussut, B. 1991. Les ostracodes du Crétacé moyen (Barrémien à Turonien), le long d'une transversale Agadir-Nador (Maroc). Strata, 2:1-765.

Antonietto, L.S.; Abrahão, A.; Do Carmo, D.A. \& Meireles, R.P. 2013. Taxonomy, biostratigraphy and paleozoogeography of Amphicytherura Butler and Jones, Aracajuia Krömmelbein and Dinglecythere Antonietto et al., n. gen. (Crustacea, Ostracoda). Marine Micropaleontology, 105:1-17. doi:10.1016/j. marmicro.2013.09.002

Apostolescu, V. 1961. Contribution a l'étude paléontologique (ostracodes) et stratigraphique des bassins crétacés et tertiaires de l'Afrique Occidentale. Revue de l'Institut Français du Pétrole, 16:779-867.

Bertels, A. 1977. Cretaceous Ostracoda - South Atlantic. In: F.M. Swain (ed.) Developments in Palaeontology and Stratigraphy, 6 - Stratigraphic Micropaleontology of Atlantic Basin and Borderlands, Elsevier, p. 271-304.

Bischoff, G. 1964. Ostracoden-Studien im Libanon, 3: Die Gattung Cytherelloidea im Oberen Jura und in der Unterkreide. Senckenbergiana Lethaea, 45:1-27.

Butler, E.A. \& Jones, D.E. 1957. Cretaceous Ostracoda of Prothro and Rayburns salt domes, Bienville parish, Louisiana. Bulletin of the Louisiana Geological Survey, 32:1-65.

Campos Neto, O.P.A.; Souza-Lima, W. \& Cruz, F.E.G. 2007. Bacia de Sergipe-Alagoas. Boletim de Geociências da PETROBRAS, 15:405-415.

Charollais. J.; Moullade, M.; Oertli, H.J. \& Rapin, F. 1977. Découverte de microfaunes de l'albien moyen et supérieur dans la Vallée de Joux (Jura vaudois, Suisse). Géobios, 10:683-695. doi:10.1016/S0016-6995(77)80047-8

Christensen, O.B. 1965. The Ostracod Genus Dicrorygma Poag, 1962 from Upper Jurassic and Lower Cretaceous. Danmarks Geologiske Undersøgelse - II Rjekke, 90:3-23.
Colin, J.P. \& Andreu, B.1990. Cretaceous Halocypridid Ostracoda. In: R. Whatley \& C. Maybury (eds.) Ostracoda and Global Events, Chapman \& Hall, p. 515-526.

Colin, J.P.; Andreu, B.; Dejax, J. \& Gèze, R. 2005. Sur l'origine du genre Microceratina Swanson, 1980 (Ostracoda, Eucytherurinae) et sa présence téthysienne dès le Jurassique supérieur. Revue de Micropaléontologie, 48:15-24. doi:10.1016/j. revmic.2004.12.005

Colin, J.P. \& Babinot, J.F. 1996. Preliminary account of ostracodes from the Aptian-Albian of Venezuela: palaeobiogeographic implications. In: M.C. Keen (ed.) Proceedings of the $2^{\text {nd }}$ European Ostracodologist Meeting, British Micropalaeontological Society, p. 29-34.

Dias-Brito, D. 2000. Global stratigraphy, palaeobiogeography and palaeoecology of Albian-Maastrichtian pithonellid calcispheres: impact on Tethys configuration. Cretaceous Research, 21:315349. doi:10.1006/cres.2000.0196

Dingle, R.V. 1999. Walvis ridge barrier: its influence on palaeoenvironments and source rock generation deduced from ostracod distributions in the early South Atlantic ocean. In: N.R. Cameron, R.H. Bate \& V.S. Clure (eds.) The Oil and Gas Habitats of the South Atlantic, London, Geological Society of London, p. 293-302 (Special Publication 153).

Do Carmo, D.A.; Coimbra, J.C.; Whatley, R.C.; Antonietto, L.S. \& Citon, R.T.P. 2013. Taxonomy of limnic Ostracoda (Crustacea) from the Alagamar Formation, middle-upper Aptian, Potiguar Basin, northeastern Brazil. Journal of Paleontology, 87:91-104. doi:10.1666/11-108R.1

Do Carmo, D.A.; Colin, J.P.; Hidalgo, P.H.P.; Meireles, R.P.; BerbertBorn, M.L.C. \& Almeida, C.M. 2012. Reassessment of the genus Sergipella Krömmelbein, 1967 (Ostracoda, Trachyleberididae), uppermost Aptian-Albian of Brazil and West Africa: taxonomy and paleogeographic distribution. Revue de Micropaléontologie, 55:3-15. doi:10.1016/j.revmic.2011.12.002

Do Carmo, D.A.; Whatley, R.; Queiroz Neto, J.V. \& Coimbra, J.C. 2008. On the validity of two Lower Cretaceous nonmarine ostracode genera: biostratigraphic and paleogeographic implications. Journal of Paleontology, 82:790-799. doi:10.1666/07-008.1

Feijó, F.J. 1994. Bacias de Sergipe e Alagoas. Boletim de Geociencias da PETROBRÁS, 8:149-161.

Graddi, J.C.S.V.; Campos Neto, O.P.A. \& Caixeta, J.M. 2007. Bacia de Jacuípe. Boletim de Geociências da PETROBRAS, 15:417-421.

Gramm, M.N. \& Kuznetsova, Z.V. 1970. Sistematicheskoye polozheniye roda Robsoniella (Ostracoda). Paleontologicheskii Zhurnal, 3:89-94.

Grosdidier, E. 1979. Principaux ostracodes marins de l'intervalle Aptien-Turonien du Gabon (Afrique Occidentale). Bulletin des Centres de Recherche Exploration-Production du Pétrole, 3:1-33.

Gründel, J. 1964. Neue Ostracoden as der deutschen Unterkreide II. Monatsberichte der Deutschen Akademie der Wissenschaften zu Berlin, 8:849-858.

Gründel, J. 1974. Zur Taxonomie und Phylogenie der Cytherettidae Triebel 1952 (Ostracoda, Crustacea). Freiberger Forschungshefte Reihe C, 298:81-99.

Kaye, P. 1965. Some new British Albian Ostracoda. Bulletin of the British Museum (Natural History), Geology, 11:215-253.

Kesling, R.V. 1951. Terminology of ostracod carapaces. Contributions from the Museum of Paleontology, University of Michigan, 1:93-171. 
Koutsoukos, E.A.M. \& Bengtson, P. 1993. Towards an integrated biostratigraphy of the upper Aptian-Maastrichtian of the Sergipe Basin, Brazil. Documents des Laboratoires de Géologie de Lyon, 125:241-262.

Koutsoukos, E.A.M. \& Dias-Brito, D. 1987. Paleobatimetria da margem continental do Brasil durante o Albiano. Revista Brasileira de Geociências, 17:86-91.

Koutsoukos, E.A.M. \& Silva-Telles Jr., A.C. 1993. Stratigraphic and palaeoenvironmental distributions of mid-Cretaceous Ostracoda from the Sergipe Basin, NE Brazil, and their biogeographic affinities with NW Africa. In: K.G. McKenzie \& P.J. Jones (eds.) Ostracoda in the Earth and Life Sciences, Balkema, p. 664.

Krömmelbein, K. 1962. Zur taxonomie und biochronologie stratigraphisch wichtiger ostracoden-arten aus der oberjurassich?unterkretazischen Bahia-Serie (Wealden-fazies) NE-Brasiliens. Senckenbergiana Lethae, 43:437-527.

Krömmelbein, K. 1964. Ostracoden aus der marinen "Küsten-Kreide" Brasiliens. 1: Brachycythere (Brachycythere) sapucariensis $\mathrm{n}$. sp. aus dem Turonium. Senckenbergiana Lethae, 45:489-495.

Krömmelbein, K. 1966. Preliminary remarks on some marine ostracodes from northeastern Brazil and West Africa. In: WEST AFRICAN MICROPALEONTOLOGICAL COLLOQUIUM, 2, 1966. Proceedings, Leiden, E.J. Brill, p. 119-123.

Krömmelbein, K. 1967. Ostracoden aus der marinen "KüstenKreide" Brasiliens. 2: Sergipella transatlantica n. g., n. sp., und Aracajuia benderi n. g., n. sp., aus dem Ober Aptium/Albium. Senckenbergiana Lethaea, 48:525-533.

Krömmelbein, K. 1975. Remarks on marine Cretaceous ostracodes of Gondwanic distribution. In: AFRICAN COLLOQUIUM ON MICROPALAEONTOLOGY, 5, 1972. Proceedings, Madrid, Enadimsa, p. 539-551.

Krömmelbein, K. \& Weber, R. 1971. Ostracoden des NordostBrasilianischen Wealden. Beihefte zum Geologischen Jahrbuch, 115:1-93.

Krömmelbein, K. \& Wenger. R. 1966. Sur quelques analogies remarquables dans les microfaunes Crétacées du Gabon et du Brésil oriental (Bahia et Sergipe). In: D. Reyre (ed.) Bassins sédimentaires du littoral Africain, Association des Services Géologiques Africains, p. 193-196.

Liebau, A. 2005. A revised classification of the higher taxa of the Ostracoda (Crustacea). Hydrobiologia, 538:115-137. doi:10.1007/s10750-004-4943-7

Lüttig, G. 1962. Zoologische und paläontologische ostracodensystematik. Paläontologische Zeitschrift, 36:154-184.

Majoran, S. 1991 Morphometric relationships among upper Cretaceous samples of Oertliella tarfayensis Reyment (Crustacea, Ostracoda). Revista Española de Paleontología, 6:117-125.

Marques, R.C. 1965. Campo petrolífero de Carmópolis: histórico da descoberta - geologia do campo - perspectivas econômicas. Boletim Técnico da PETROBRÁS, 8:307-328.
Mertens, E. 1956. Zur Grenzziehung Alb/Cenoman in Nordwestdeutschland mit Hilfe von Ostracoden. Geologisches Jahrbuch, Reihe B, 72:174-230.

Murphy, M.A. \& Salvador, A. 1999. International Stratigraphic Guide. An abridged version. Episodes, 22:255-271.

Piovesan, E.K.; Nicolaidis, D.D.; Fauth, G. \& Viviers, M.C. 2013. Ostracodes from the Aptian-Santonian of the Santos, Campos and Espírito Santo basins, Brazil. Journal of South American Earth Sciences, 48:240-254. doi:10.1016/j.jsames.2013.09.012

Ponte, F.C. \& Asmus, H.E. 1976. The Brazilian marginal basins: current state of knowledge. Anais da Academia Brasileira de Ciências, Suplemento, 48:215-289.

Poropat, S.F. \& Colin, J.P. 2012. Reassessment of the Early Cretaceous non-marine ostracod genera Hourcqia Krömmelbein, 1965 and Pattersoncypris Bate, 1972 with the description of a new genus, Kroemmelbeincypris. Journal of Paleontology, 86:700-720. doi:10.1666/11-140R.1

Puckett, T.M. 2002. Systematics and paleobiogeography of Brachycytherine Ostracoda. Micropaleontology, 48:1-87.

Reyment, R.A. 1978. Quantitative biostratigraphical analysis exemplified by Moroccan Cretaceous ostracods. Micropaleontology, 24:24-43.

Reyment, R.A. 1980. Paleo-oceanology and paleobiogeography of the Cretaceous South Atlantic ocean. Oceanologica Acta, 3:127-133.

Rosenfeld, A. \& Raab, M., 1983. Lower Cretaceous ostracodes from Israel and Sinai. Israel Journal of Earth Sciences, 33:85-134.

Schaller, H. 1969. Revisão estratigráfica da bacia de SergipeAlagoas. Boletim Técnico da PETROBRÁS, 12:21-86.

Souza-Lima, W.; Andrade, E.J.; Bengston, P. \& Galm, P.C. 2002. A bacia de Sergipe-Alagoas: evolução geológica, estratigrafia e conteúdo fóssil. Phoenix, Edição Especial, 1:1-34.

Swain, F.M. 1976. Lower and Middle? Cretaceous Ostracoda from the Atlantic ocean off Guiana and off West Africa. Journal of Paleontology, 50:734-753.

Sylvester-Bradley, P.C. \& Benson, R.H. 1971. Terminology for surface features in ornate ostracodes. Lethaia, 4:249-286.

Tambareau, Y. 1982. Les ostracodes et l'histoire géologique de l'Atlantique Sud au Crétacé. Bulletin des Centres de Recherche et Exploration-Production Elf-Aquitaine, 6:1-37.

Viviers, M.C.; Koutsoukos, E.A.M.; Silva-Telles Jr., A.C. \& Bengtson, P. 2000. Stratigraphy and biogeographic affinities of the late Aptian-Campanian ostracods of the Potiguar and Sergipe basins in northeastern Brazil. Cretaceous Research, 21:407-455. doi:10.1006/cres.2000.0205

Received in December, 2014; accepted in September, 2015. 